\title{
STUDY ON HEAVY METAL CONTAMINATION DISTRIBUTION AT ACTIVE LANDFILL AT DIFFERENT DEPTHS AND RADIUSES
}

\author{
OTHMAN, R..$^{1 *}$ - MOHD LATIFF, N. H. ${ }^{1}-$ BAHARUdDIN, Z. M. ${ }^{1}-$ HASHIM, K. S. H. Y $.^{2}-$ \\ LUKMAN HAKIM MAHAMOD, L. H. ${ }^{3}$ \\ ${ }^{1}$ International Institute for Halal Research and Training (INHART) \\ Department of Landscape Architecture, Kulliyyah of Architecture and Environmental Design \\ (KAED), International Islamic University Malaysia, 53100 Kuala Lumpur, Malaysia \\ ${ }^{2}$ Department of Urban \& Regional Planning, Kulliyyah of Architecture and Environmental \\ Design (KAED), International Islamic University Malaysia, 53100 Kuala Lumpur, Malaysia \\ ${ }^{3}$ Department of Quantity Surveying, Kulliyyah of Architecture and Environmental Design \\ (KAED), International Islamic University Malaysia, 53100 Kuala Lumpur, Malaysia \\ "Corresponding author \\ e-mail: rashidi@iium.edu.my; phone: +60-126-644-772; fax: +60-361-964-864
}

(Received 24 $4^{\text {th }}$ Jan 2019; accepted $3^{\text {rd }}$ May 2019)

\begin{abstract}
Landfilling is more preferable in Malaysia compared to another disposal method due to low cost, and availability of land. Other than solid waste, the percolation of water into the landfill leads to leachate formation. The migration of waste in leachate form may accelerate the heavy metal contamination of the soil one of the major concerns in landfilling. This study aimed in comparing soil samples taken from five different sites in Selangor of inert waste (Sungai Kertas, Kuang and Dengkil) and sanitary (Tanjung Dua Belas and Jeram) landfills at different depths $(0-30 \mathrm{~cm}, 30-60 \mathrm{~cm}$ and $60-90 \mathrm{~cm})$ and radiuses $(5-10 \mathrm{~m}$, 10-15 $\mathrm{m}$ and 15-20 m), for ten heavy metals ( $\mathrm{Al}, \mathrm{Cr}, \mathrm{Mn}, \mathrm{Fe}, \mathrm{Co}, \mathrm{Ni}, \mathrm{Cu}, \mathrm{Zn}, \mathrm{Cd}$ and $\mathrm{Pb}$ ) to find the risk of heavy metal movement from the upper layer cell into the deeper layer of the soil block. All the data were analysed using ICP-MS (Perkin Elmer NexION 300X). Al and Fe displayed high concentration at most of the sites especially at the deeper depth of the soil.

Keywords: urban pollution, landfill, active sanitary landfills, inorganic pollutant, leachate, municipal solid waste
\end{abstract}

\section{Introduction}

According to Agamuthu et al. (2014) and Yusoff et al. (2013), there is a total of about 251 landfills of different sizes and ages recognized officially in Malaysia. Out of these, 111 were closed and 150 are active landfills. These active landfills include 77 open dumpsites, 49 open-tipping sites, 19 landfills without leachate treatment, 10 landfills with leachate treatment, and 6 are sanitary (engineered). In Malaysia, proper disposal of solid waste at sanitary landfills constitute only a small portion of a whole and was built recently compared to open dumps which constitute around $90 \%$ of all the waste disposal sites (Agamuthu and Fauziah, 2011; Sharifah and Latifah, 2013).

Selangor as one of the most developed states in Malaysia has produced the highest MSW per capita due to the high standard of living (Agamuthu, 2001; Leete, 2002). Studies reported that Selangor is responsible for one-third of the total amount of solid waste generated in Malaysia with 3,923 tons daily (Riber et al., 2005; Ismail and Manaf, 2013; Sharifah and Latifah, 2013). Twelve landfill sites from a total of 20 landfill sites in Selangor (closed and operating) are considered as open dumpsites with level 0 sanitary 
classification, which generate the highest risk of contamination and leachate migration. In addition, all 20 landfills are located in 5 main river basins where the Sungai Selangor Basin has the highest number of operating landfills (three) and four closed landfills. The classification is as followings; Level 0: Open dumping; Level I: Controlled tipping; Level II: Sanitary landfill with a bund and daily soil cover; Level III: Sanitary landfill with leachate recirculation system; and Level IV: Sanitary landfill with leachate treatment facilities.

Sanitary landfilling and open dumping are commonly known across the world as disposal of municipal solid waste (MSW) method. Sanitary landfilling is predominantly practiced in developed nations while open dumping is common in low-income and developing nations (Yahaya, 2016). An open dump is a primitive and non-sanitary waste disposal site where indiscriminate wastes are improperly tipped or dumped in a preexisting hole or on the side of a hill without proper maintenance (Agamuthu, 2001; Blight, 2008). As an alternative, a sanitary landfill utilizes the principles of engineering to ensure the protection of the environment and public health while providing safe longterm disposal of solid wastes (American Society of Civil engineers, 1959). In Malaysia, municipal solid waste is disposed of in both the newer sanitary landfills and older open dumps.

The increasing of waste generation due to this municipal solid waste, however, shortens the span of a landfill. Thus, more and more new areas have to be converted into disposal sites. The negative impacts of MSW landfill on the environment cause a wide range of concern. It includes the risk of explosion, odor problem, leachate seeping into surface and groundwater system, as well as, soil contamination due to heavy metal sourced from disposed waste (Fauziah and Agamuthu, 2005). Contaminated soil remediation is reported as one of the most expensive technologies in environmental management.

Based on the previous study, most organic chemical substances will eventually either be degraded through biochemical reactions in the landfill or be leached out of the landfill with water movement. However, the majority of heavy metals will remain in the landfill because heavy metal migration is very limited compared to the number of metals accumulated in the landfill (Øygard et al., 2004; Riber et al., 2004), especially in anaerobic processes. The slow movement of heavy metals is the result of heavy metals being subjected to strong sorption on soil particles, precipitation under anaerobic conditions, and chelation with inorganic and organic ligands in landfills (Bozkurt et al., 1999, 2000). Heavy metal contamination is mainly due to the subsequent migration of leachate from and within the landfill's waste cell. The natural process taking place within the boundaries of the waste cells accelerate the process of heavy metal leaching from the waste component. Various types of wastes are the main sources of heavy metal within a landfill system. This includes metal waste components such as food cans and scrap metal and the indiscriminate dumping of household hazardous waste and electronic waste such as batteries and old computer. The release of heavy metal into the adjacent environment is a serious environmental concern and a threat to public health and safety.

\section{Material and methods}

\section{Study area description}

Five active landfill sites ( 3 non-sanitary landfills and 2 sanitary landfills) located at Selangor, Malaysia namely; Sungai Kertas non-sanitary landfill $\left(3^{\circ} 15^{\prime} 52.5^{\prime \prime} \mathrm{N}\right.$ 
$\left.101^{\circ} 41^{\prime} 05.1^{\prime \prime E}\right)$, Kuang non-sanitary landfill $\left(3^{\circ} 15^{\prime} 31.4^{\prime \prime N} 101^{\circ} 33^{\prime} 50.0^{\prime \prime E}\right)$, Dengkil non-sanitary landfill $\left(2^{\circ} 52^{\prime} 12.2^{\prime \prime} \mathrm{N} 101^{\circ} 38^{\prime} 54.1^{\prime \prime E}\right)$, Tanjung Dua Belas sanitary landfill $\left(2^{\circ} 43^{\prime} 48.9^{\prime \prime} \mathrm{N} \mathrm{101}{ }^{\circ} 36^{\prime} 21.7^{\prime \prime E}\right)$ and Jeram sanitary landfill $\left(3^{\circ} 11^{\prime} 23.8^{\prime \prime} \mathrm{N} \mathrm{101}{ }^{\circ} 21^{\prime} 54.3^{\prime \prime E}\right)$ were selected for this study. The site selection was based on the types of the landfill and the size of the landfill located in Selangor state. Table 1 indicates the landfill sites info with the area covered, wasted collected, total year of operation and the current status of the landfill studied.

Table 1. Selected landfill sites with the area covered, waste collected per day, total year operation and current status

\begin{tabular}{c|c|c|c|c|c}
\hline Landfill Sites & Area (Acre) & $\begin{array}{c}\text { Waste Collected } \\
\text { (Tone/Day) }\end{array}$ & $\begin{array}{c}\text { Total Year } \\
\text { Operation }\end{array}$ & Current Status & Source \\
\hline $\begin{array}{c}\text { Kampung Sungai Kertas } \\
\text { Inert Waste }\end{array}$ & 14.19 & 130 & 7 & Active & $\begin{array}{c}\text { Othman et al. } \\
(2016)\end{array}$ \\
\hline $\begin{array}{c}\text { Kuang Inert Waste Landfill } \\
\text { Dengkil Inert Waste } \\
\text { Landfill }\end{array}$ & 145 & 50 & 11 & Active & $\begin{array}{c}\text { Tengku Ibrahim et } \\
\text { al. (2017) }\end{array}$ \\
\hline $\begin{array}{c}\text { Tanjung 12 Sanitary } \\
\text { Landfill }\end{array}$ & 160 & 1000 & 25 & Active & $\begin{array}{c}\text { Othman et al. } \\
(2016)\end{array}$ \\
\hline $\begin{array}{c}\text { Jeram Sanitary Landfill } \\
\text { Danget al. }\end{array}$ & 160 & 2500 & 16 & Active & $\begin{array}{c}\text { Yahaya et alve } \\
(2016)\end{array}$ \\
\hline
\end{tabular}

\section{Soil sampling}

Soil samples were collected at different points (0-200 mm depth, approx. $1000 \mathrm{~g})$ were taken by using soil auger (Eijkelkamp Agrisearch). The soil then was sealed in a polyethylene bag and labeled. The soil was dried in an oven for $70^{\circ} \mathrm{C}$ for 3 days to a week depending on the moistness of the soil. Then samples were ground by using agate mortar until becoming small particles. Then it was sieved using a $2 \mathrm{~mm}$ mesh to remove stones and plant materials. Then samples were stored at room temperature before being digested using Microwave Digestion Ethos D (Milestone, 2001). Heavy metals, Al, Cr, $\mathrm{Mn}, \mathrm{Fe}, \mathrm{Co}, \mathrm{Ni}, \mathrm{Cu}, \mathrm{Zn}, \mathrm{Cd}$, and $\mathrm{Pb}$ were then analysed by using ICP-MS (Perkin Elmer NexION 300X).

\section{Heavy metals digestion and analysis}

$0.5 \mathrm{~g}$ of soil samples were accurately weighed into a container made of PFA perfluoroalkoxy polymer and digested through a microwave digestion system using the digestion method as described by Zhao et al. (1994). Soil samples were air-dried and sieved. Soil samples were passed through a $2 \mathrm{~mm}$ sieve and ready for further analysis. Dried and the ground sample was mixed with $10 \mathrm{ml}$ of concentrated nitric acid $\left(\mathrm{HNO}_{3} 65 \%\right)$ and digested. Acid was added for each soil samples and then the digestion tubes were placed in a rotor segment by using a torque wrench. The segments were inserted into the microwave cavity and connected with the temperature sensor. The mixture temperature was adjusted to $\pm 175^{\circ} \mathrm{C}$ and 1,200 Watt of power for 30 minutes using Microwave Digestion (Milestone Start D) as detailed in Method US EPA 3051. The digestion was completed after the last solution was clear and no brownish fumes were released from the digestion vessel tubes. When digestion was completed, samples 
were removed and diluted. The soil digests were adjusted to the final volume of $50 \mathrm{~mL}$ with deionized water. This solution is further 1:1 diluted for the analysis of components by ICP-MS and divided into triplicate each into $15 \mathrm{ml}$ tubes.

\section{Data Analysis}

All the experiments were carried out in triplicates and data presented as mean values of three independent replicates. Data were further analysed using analysis of variance (ANOVA). Statistical analysis for all experiments was performed by using SAS through factorial analysis of variance followed by Tukey's test with significant different at $P<0.0001$.

\section{Results and discussion}

\section{Sungai Kertas Inert Waste non-sanitary landfill}

The results in Fig. 1 showed heavy metal concentration in an active non-sanitary landfill with a radius of 5 to $10 \mathrm{~m}, 10$ to $15 \mathrm{~m}$ and 15 to $20 \mathrm{~m}$ at different depth 0 to $30 \mathrm{~cm}, 30$ to $60 \mathrm{~cm}$ and 60 to $90 \mathrm{~cm}$ of Sungai Kertas non-sanitary landfill. Results of heavy metal showed that $\mathrm{Al}$ and Fe concentration is higher at all point of Sungai Kertas landfill.

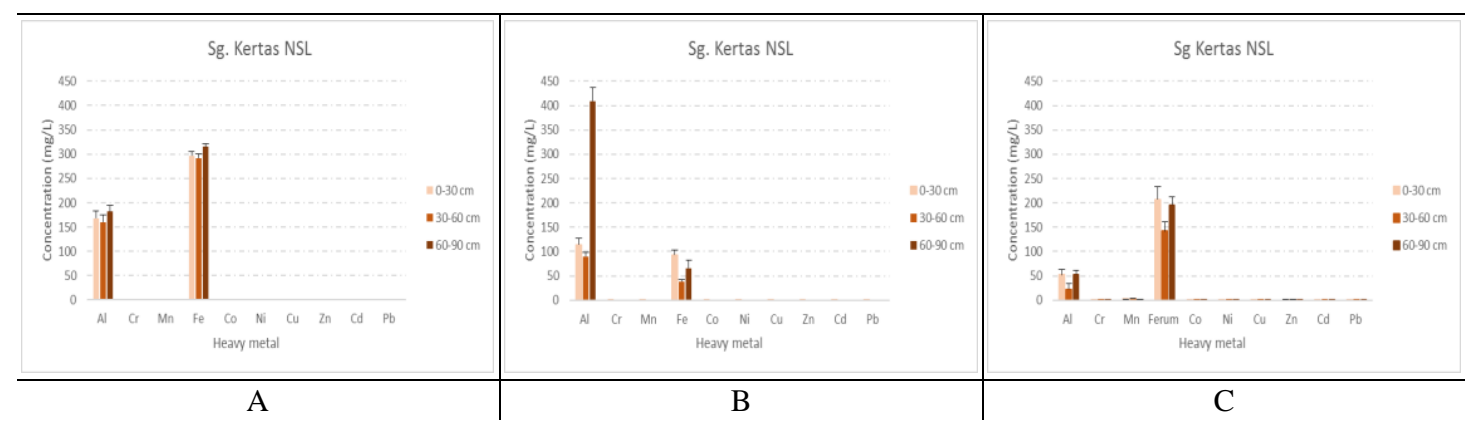

Figure 1. The pattern of 10 heavy metal concentration depicted Sungai Kertas non-sanitary landfill at different soil depths $(0-30 \mathrm{~cm}, 30-60 \mathrm{~cm}$, and $60-90 \mathrm{~cm})$ and radiuses $(A: 5-10 \mathrm{~m}, \mathrm{~B}$ : $10-15 \mathrm{~m}$ and $\mathrm{C}: 15-20 \mathrm{~m}$ ) of the active landfill

Among the analyzed heavy metals, Al had the highest concentrations up to 409.786 $\mathrm{mg} / \mathrm{kg}$ within active non-sanitary soil heavy metal concentration. Compared altogether between these three radiuses of Sungai Kertas non-sanitary landfill, the heavy metal concentration at radius 5 to $10 \mathrm{~m}$ showed the highest result for $\mathrm{Fe} ; 297.023 \mathrm{mg} / \mathrm{kg}$, $291.954 \mathrm{mg} / \mathrm{kg}$ and $314.758 \mathrm{mg} / \mathrm{kg}$. The lowest results showed by $\mathrm{Al}$ at radius 15 to 20 $\mathrm{m} ; 52.089 \mathrm{mg} / \mathrm{kg}, 22.256 \mathrm{mg} / \mathrm{kg}$ and $53.188 \mathrm{mg} / \mathrm{kg}$ meanwhile $\mathrm{Fe}$ at radius 10 to $15 \mathrm{~m}$ showed $93.175 \mathrm{mg} / \mathrm{kg}, 38.714 \mathrm{mg} / \mathrm{kg}$ and $65.584 \mathrm{mg} / \mathrm{kg}$.

\section{Kuang Inert Waste non-sanitary landfill}

The results in Fig. 2 showed heavy metal concentration in an active non-sanitary landfill with a radius of 5 to $10 \mathrm{~m}, 10$ to $15 \mathrm{~m}$ and 15 to $20 \mathrm{~m}$ at different depth 0 to $30 \mathrm{~cm}, 30$ to $60 \mathrm{~cm}$ and 60 to $90 \mathrm{~cm}$ of Kuang non-sanitary landfill. Results of heavy metal showed that the highest concentration is depicted by Fe. The concentration is 
higher at the centre and the middle point of Kuang landfill. Compared altogether between these three radius of Kuang non-sanitary landfill, heavy metal concentration showed the highest result for $\mathrm{Fe}$ at the radius 15 to $20 \mathrm{~m} ; 593.954 \mathrm{mg} / \mathrm{kg}, 546.171$ $\mathrm{mg} / \mathrm{kg}$ and $570.699 \mathrm{mg} / \mathrm{kg}$ and radius 10 to $15 \mathrm{~m} ; 433.383 \mathrm{mg} / \mathrm{kg}, 235.407 \mathrm{mg} / \mathrm{kg}$ and $230.230 \mathrm{mg} / \mathrm{kg}$. The lowest results showed by Al at radius 10 to $15 \mathrm{~m} ; 22.311 \mathrm{mg} / \mathrm{kg}$, $36.557 \mathrm{mg} / \mathrm{kg}$ and $32.934 \mathrm{mg} / \mathrm{kg}$ well as radius 5 to $10 \mathrm{~m} ; 44.811 \mathrm{mg} / \mathrm{kg}, 29.436 \mathrm{mg} / \mathrm{kg}$ and $36.277 \mathrm{mg} / \mathrm{kg}$.

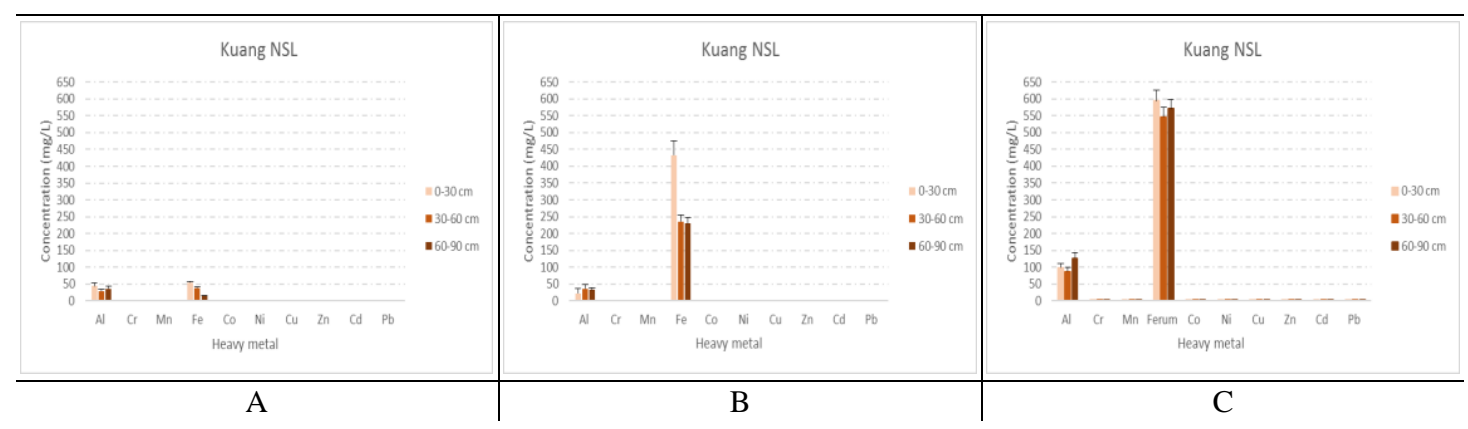

Figure 2. The pattern of 10 heavy metal concentration depicted Kuang non-sanitary landfill at different soil depths $(0-30 \mathrm{~cm}, 30-60 \mathrm{~cm}$, and $60-90 \mathrm{~cm})$ and radiuses $(A: 5-10 \mathrm{~m}, \mathrm{~B}: 10-15 \mathrm{~m}$ and $C: 15-20 \mathrm{~m}$ ) of the active landfill

\section{Dengkil Inert Waste non-sanitary landfill}

The results in Fig. 3 showed heavy metal concentration in an active non-sanitary landfill with a radius of 5 to $10 \mathrm{~m}, 10$ to $15 \mathrm{~m}$ and 15 to $20 \mathrm{~m}$ at different depth 0 to $30 \mathrm{~cm}, 30$ to $60 \mathrm{~cm}$ and 60 to $90 \mathrm{~cm}$ of Dengkil non-sanitary landfill. Results of heavy metal showed that the highest concentration is depicted by Al. The concentration is higher at radius 10 to $15 \mathrm{~m}$ of Dengkil landfill.

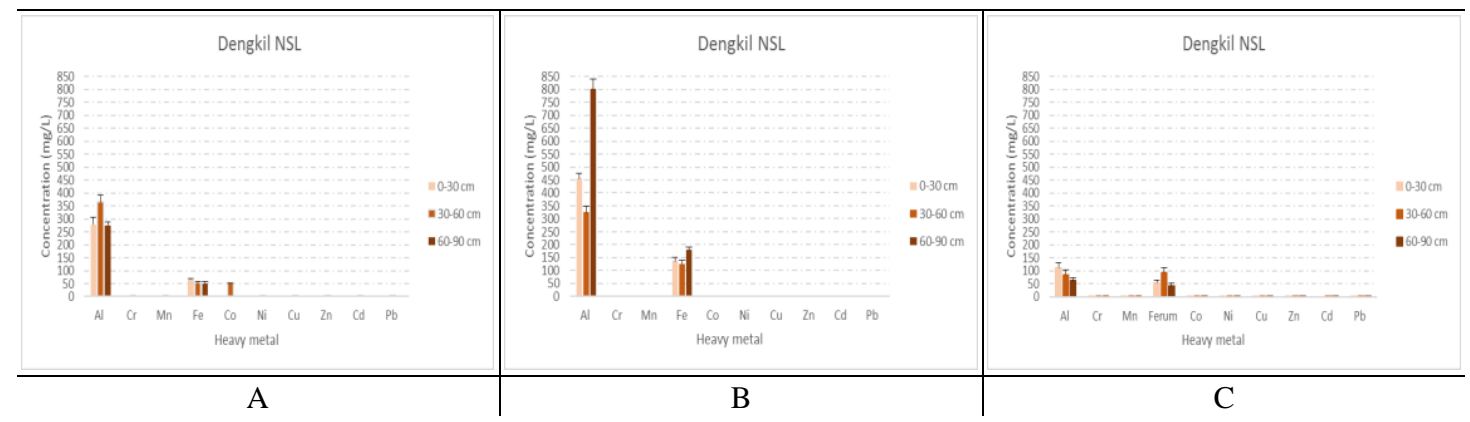

Figure 3. The pattern of 10 heavy metal concentration depicted Dengkil non-sanitary landfill at different soil depths $(0-30 \mathrm{~cm}, 30-60 \mathrm{~cm}$, and $60-90 \mathrm{~cm})$ and radiuses $(A: 5-10 \mathrm{~m}, \mathrm{~B}: 10-15 \mathrm{~m}$ and $C: 15-20 \mathrm{~m}$ ) of the active landfill

Compared altogether between these three radiuses of Dengkil non-sanitary landfill, heavy metal concentration showed the highest result for $\mathrm{Al}$ at radius 10 to $15 \mathrm{~m}$; $455.457 \mathrm{mg} / \mathrm{kg}, 325.270 \mathrm{mg} / \mathrm{kg}$ and $800.804 \mathrm{mg} / \mathrm{kg}$ followed by radius 5 to $10 \mathrm{~m}$; $278.700 \mathrm{mg} / \mathrm{kg}, 364.215 \mathrm{mg} / \mathrm{kg}$ and $275.386 \mathrm{mg} / \mathrm{kg}$. The lowest results showed by Fe at all point. The highest concentration for $\mathrm{Fe}$ showed by radius 10 to $15 \mathrm{~m}$; 
$137.191 \mathrm{mg} / \mathrm{kg}, 126.688 \mathrm{mg} / \mathrm{kg}$ and $178.860 \mathrm{mg} / \mathrm{kg}$ followed by radius 15 to $20 \mathrm{~m}$; $54.143 \mathrm{mg} / \mathrm{kg}, 93.842 \mathrm{mg} / \mathrm{kg}$ and $41.216 \mathrm{mg} / \mathrm{kg}$ then radius 5 to $10 \mathrm{~m} ; 65.457 \mathrm{mg} / \mathrm{kg}$, $52.985 \mathrm{mg} / \mathrm{kg}$ and $51.282 \mathrm{mg} / \mathrm{kg}$. There is a concentration of Co that showed up to $52.985 \mathrm{mg} / \mathrm{kg}$ at $30-60 \mathrm{~cm}$ depth for radius 5 to $10 \mathrm{~m}$.

\section{Tanjung Dua Belas sanitary landfill}

The results in Fig. 4 showed heavy metal concentration in an active sanitary landfill with a radius of 5 to $10 \mathrm{~m}, 10$ to $15 \mathrm{~m}$ and 15 to $20 \mathrm{~m}$ at different depth 0 to $30 \mathrm{~cm}, 30$ to $60 \mathrm{~cm}$ and 60 to $90 \mathrm{~cm}$ of Tanjung Dua Belas sanitary landfill. Results of heavy metal showed that the highest concentration is depicted by $\mathrm{Fe}$ and $\mathrm{Al}$. The concentration is higher at radius 10 to $15 \mathrm{~m}$ of Tanjung Dua Belas landfill. Compared altogether between these three radiuses of Tanjung Dua Belas sanitary landfill, heavy metal concentration showed the highest result for $\mathrm{Al}$ at radius 10 to $15 \mathrm{~m} ; 85.182 \mathrm{mg} / \mathrm{kg}$, $159.445 \mathrm{mg} / \mathrm{kg}$ and $567.264 \mathrm{mg} / \mathrm{kg}$ followed by Fe; $113.967 \mathrm{mg} / \mathrm{kg}, 161.552 \mathrm{mg} / \mathrm{kg}$ and $321.409 \mathrm{mg} / \mathrm{kg}$. The radius 15 to $20 \mathrm{~m}$ concentration also lead by $\mathrm{Al}$ and $\mathrm{Fe}$. Each showed $133.694 \mathrm{mg} / \mathrm{kg}, 120.739 \mathrm{mg} / \mathrm{kg}, 137.235 \mathrm{mg} / \mathrm{kg}$ for $\mathrm{Al}$ concentration and $170.976 \mathrm{mg} / \mathrm{kg}, 83.036 \mathrm{mg} / \mathrm{kg}$ and $162.968 \mathrm{mg} / \mathrm{kg}$ for Fe concentration. Meanwhile, at a radius 5 to $10 \mathrm{~m}$, the concentration showed almost equal between $\mathrm{Al}$ and $\mathrm{Fe}$. $\mathrm{Al}$ concentration at radius 5 to $10 \mathrm{~m} ; 104.207 \mathrm{mg} / \mathrm{kg}, 138.692 \mathrm{mg} / \mathrm{kg}$ and $136.317 \mathrm{mg} / \mathrm{kg}$ followed by Fe; $120.165 \mathrm{mg} / \mathrm{kg}, 106.395 \mathrm{mg} / \mathrm{kg}$ and $103.827 \mathrm{mg} / \mathrm{kg}$.

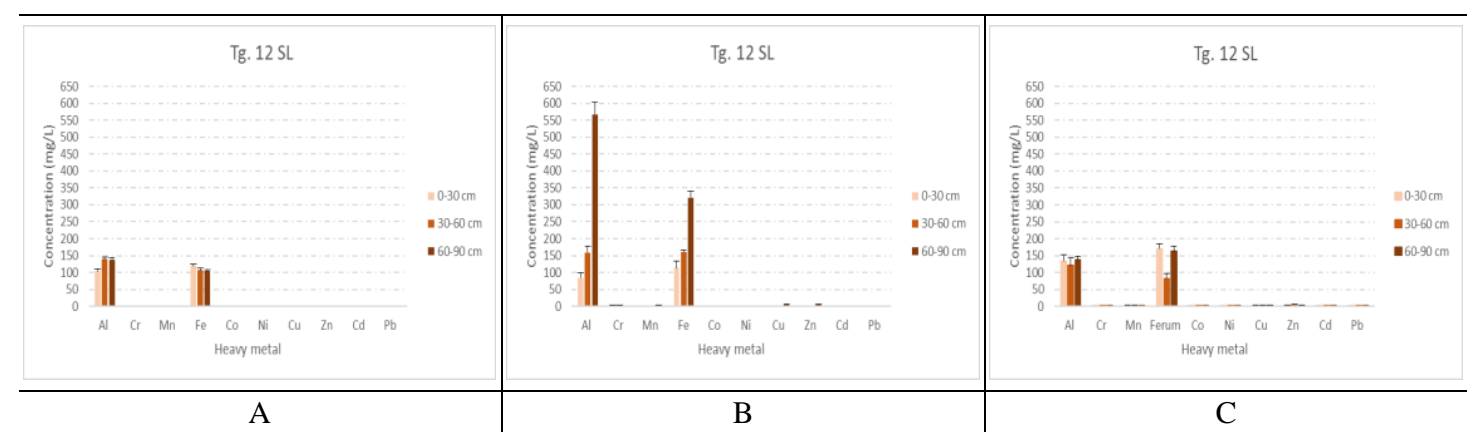

Figure 4. The pattern of 10 heavy metal concentration depicted Tanjung Dua Belas sanitary landfill at different soil depths $(0-30 \mathrm{~cm}, 30-60 \mathrm{~cm}$, and $60-90 \mathrm{~cm})$ and radiuses $(A: 5-10 \mathrm{~m}, \mathrm{~B}$ : $10-15 \mathrm{~m}$ and $\mathrm{C}: 15-20 \mathrm{~m}$ ) of the active landfill

\section{Jeram sanitary landfill}

The results in Fig. 5 showed heavy metal concentration in an active sanitary landfill with a radius of 5 to $10 \mathrm{~m}, 10$ to $15 \mathrm{~m}$ and 15 to $20 \mathrm{~m}$ at different depth 0 to $30 \mathrm{~cm}, 30$ to $60 \mathrm{~cm}$ and 60 to $90 \mathrm{~cm}$ of Jeram sanitary landfill. Results of heavy metal showed that the highest concentration is depicted by Fe and Al. The concentration is higher at the radius 15 to $20 \mathrm{~m}$ of Jeram landfill. Compared altogether between these three radiuses of Jeram sanitary landfill, heavy metal concentration showed the highest result for $\mathrm{Al}$ and $\mathrm{Fe}$ at radius 15 to $20 \mathrm{~m}$; each at $219.009 \mathrm{mg} / \mathrm{kg}$ and $232.830 \mathrm{mg} / \mathrm{kg}$ for 0 to $30 \mathrm{~cm}$ depth. Followed by Fe at radius 10 to $15 \mathrm{~m} ; 239.127 \mathrm{mg} / \mathrm{kg}$ for 30 to $60 \mathrm{~cm}$ depth. Meanwhile, for $\mathrm{Al}$ and $\mathrm{Fe}$ concentration at radius 5 to $10 \mathrm{~m}$ showed almost equal readings at all depth. Each showed $32.632 \mathrm{mg} / \mathrm{kg}, 82.432 \mathrm{mg} / \mathrm{kg}$ and $52.744 \mathrm{mg} / \mathrm{kg}$ for $\mathrm{Al}$ and $104.709 \mathrm{mg} / \mathrm{kg}, 168.297 \mathrm{mg} / \mathrm{kg}$ and $151.001 \mathrm{mg} / \mathrm{kg}$ for Fe. 
Analysis of variance confirmed the findings by exhibiting highly significant differences $(P<0.0001)$ between the radius, depth, and heavy metal concentration at three different radiuses, three different depths, and ten heavy metals concentration. This clearly demonstrates that environmental factors and landfill area background can have an important influence on the accumulation of certain heavy metal and its content. Al and Fe concentration showed the highest pattern on all 4 active landfill sites. This might probably cause by the transportation of metals that may vary between relatively unpolluted systems and disturbed or polluted systems as well as the site context. Particulate transport is dominant in unpolluted systems where metal inputs are principally from the erosion of watershed substrates (Elder, 1989).

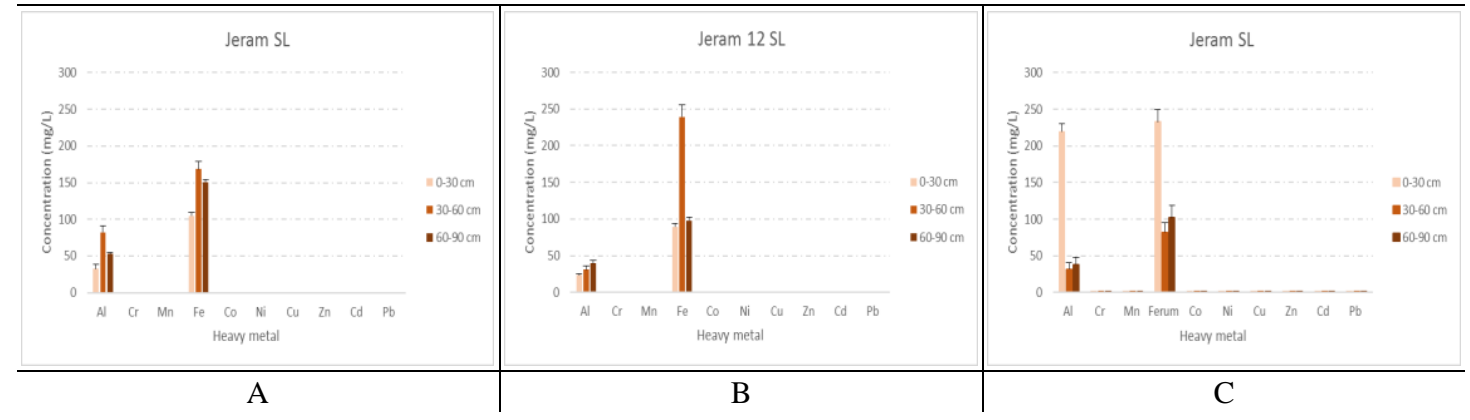

Figure 5. The pattern of 10 heavy metal concentration depicted Jeram sanitary landfill at different soil depths $(0-30 \mathrm{~cm}, 30-60 \mathrm{~cm}$, and $60-90 \mathrm{~cm})$ and radiuses $(A: 5-10 \mathrm{~m}, \mathrm{~B}: 10-15 \mathrm{~m}$ and $C: 15-20 \mathrm{~m}$ ) of the active landfill

In disturbed or polluted systems, for example, those affected by acid-mine drainage, point sources commonly deliver metals in a soluble phase or associated with organic matter, and the proportion of dissolved metals and their bioavailability tends to be higher (Solomons and Förstner, 1984). Leachate is still being produced even though most of the non-sanitary landfills in Selangor have been closed or still operating. This leachate production still occurs and badly affect the nearest water system and soil due to the location of the landfills near the water system as a source of water to the local residents. Therefore, environmental factors and landfill area background can have an important influence on the accumulation of certain heavy metal and its content. There are high contaminants levels in the groundwater underneath the non-engineered waste disposal sites in Selangor. The rate and amount of pollutant penetration through the soil is also influencing the concentration of heavy metal present in the landfill environment and finally lead to different capability depiction of heavy metal binding in the soil.

\section{Conclusions}

It can be summarised that heavy metal contents in Sungai Kertas non-sanitary landfill, Kuang non-sanitary landfill, Dengkil non-sanitary landfill, Tanjung Dua Belas sanitary landfill and Jeram sanitary landfill were accumulated by high $\mathrm{Al}$ and $\mathrm{Fe}$. A few of the landfills had been exposed to $\mathrm{Cr}, \mathrm{Mn}, \mathrm{Zn}, \mathrm{Co}$, and $\mathrm{Cu}$ below $5.0 \mathrm{mg} / \mathrm{kg}$. They are Sungai Kertas non-sanitary landfill, Dengkil non-sanitary landfill and Tanjung Dua Belas sanitary landfill. Kuang non-sanitary landfill and Jeram sanitary landfill showed only $\mathrm{Al}$ and $\mathrm{Fe}$ contaminations. In other words, there are particular locations as well as 
depth and radius where specific heavy metals signature accumulates with high concentration levels and some with low level. This raises the importance and needs for an effective potential model system for future research to investigate in depth the environmental factors such as the type of soil and waste that influence heavy metals profile and distribution or controlling heavy metals accumulation.

Acknowledgements. The research was supported by the Ministry of Higher Education Malaysia (MOHE) and International Islamic University Malaysia (IIUM) under research grant PRIGS18-021-0021.

\section{REFERENCES}

[1] Agamuthu, P. (2001): Solid waste: Principles and management, with Malaysian case studies. - University of Malaya Press 395.

[2] Agamuthu, P., Fauziah, S. H. (2011): Challenges and issues in moving towards sustainable landfilling in a transitory country, Malaysia. - Waste Management \& Research, The Journal of the International Solid Wastes and Public Cleansing Association ISWA 29(1): 13-19.

[3] Agamuthu, P., Yee, C. W., Rahedah, S., Nithyarubini, T., Boon Tien, L., Jayanthi, B. (2014): Enhancement of landfill methane oxidation using different types of organic wastes. - Environmental Earth Science 73(5): 2489-2496.

[4] American Society of Civil Engineers, ASCE (1959): Sanitary Landfill Manual of Practice. - ASCE, New York USA 61.

[5] Blight, G. E. (2008): Slope failures in municipal solid waste dumps and landfills: a review. - Waste Management and Research 26(5): 448-463.

[6] Bozkurt, S., Moreno, L., Neretnieks, I. (1999): Long term fate of organics in waste deposits and its effect on metal release. - Science of the Total Environment 228: 135-152.

[7] Bozkurt, S., Moreno, L., Neretnieks, I. (2000): Long term process in waste deposits. Science of the Total Environment 250: 101-121.

[8] Elder, J. F. (1989): Metal biogeochemistry in surface-water systems-A review of principles and concepts: U.S. - Geological Survey Circular 1013: 43.

[9] Fauziah, S. H., Agamuthu, P. (2005): Pollution Impacts of MSW Landfill Leachate. Malaysian Journal of Science 24: 31-37.

[10] Ismail, S. N. S., Manaf, L. A. (2013): The challenge of future landfill: A case study of Malaysia. - Journal of Toxicology and Environmental Health Sciences 5(6): 86-96.

[11] Leete, R. (2005): Selangor's Human Development: Progress and Challenges. - United Nations Development Programme (UNDP) http://dspace.cigilibrary.org/jspui/ handle/123456789/20421.

[12] Othman, R., Ali, Q. A. M., Ramya, R. (2016): Contamination composition of Fe, Mn and $\mathrm{Al}$ at 8 different profiles of solid waste disposal areas in Malaysia. - Int. Journal of Environ. Science and Dev 7(5): 395-398.

[13] Øygard, J. K., Mage, A., Gjengedal, E. (2004): Estimation of the mass-balance of selected metals in four sanitary landfills inWestern Norway, with emphasis on the heavy metal content of the deposited waste and the leachate. - Water Res 38: 2851-2858.

[14] Riber, C., Fredriksen, G. S., Christensen, T. H. (2005): Heavy metal content of combustible municipal solid waste in Denmark. - Waste Management \& Research 23: 126-132.

[15] Saheri, S., Mir, M. A., Basri, N. E. A., Mahmood, N. Z., Begum, R. A. (2012): Life cycle assessment for solid waste disposal options in Malaysia. - Polish Journal of Environmental Studies 21(5): 1377-1382.

[16] Sharifah, N. S. I., Latifah, A. M. (2013): The challenge of future landfill: A case study of Malaysia. - Journal of Toxicology and Environmental Health Sciences 5(6): 86-96. 
[17] Simmons, R. W., Pongsakul, P., Saiyasitpanich, D., Klinphoklap, S. (2004): Cadmium contamination of soil and rice in a case study location in Thailand: Impliations for public health and potential management options. - International Symposium on Phytoremediation Technology.

[18] Tarmudi, Z., Abdullah, M. L., Tap, A. O. M. (2012): An overview of municipal solid wastes generation in Malaysia. - JurnalTeknologi 51(1): 1-15.

[19] Tengku Ibrahim, T. N. B., Othman, F., Mahmood, N. Z. (2017): Assessment of water quality of Sembilang River receiving effluent from controlled municipal solid waste (MSW) landfill in Selangor. - International Technical Postgraduate Conference IOP Conference Series: Materials Science and Engineering 210.

[20] Yahaya, N. S., Choun, S. L., Taha, M. R., Joy, J. P. (2016): Exposure of municipal solid waste disposal sites to climate related geohazards: Case study of Selangor. - Bulletin of the Geological Society of Malaysia 62: 57-63.

[21] Yusoff, I., Alias, Y., Yusof, M., Ashraf, M. A. (2013): Assessment of pollutants migration at Ampar Tenang landfill site, Selangor, Malaysia. - Science Asia 39: 392-409.

[22] Zhao, F., McGrath, S. P., Crosland, A. R. (1994): Comparison of three wet digestion methods for determination of plant sulphur by inductively coupled plasma atomic emission spectroscopy (ICP-AES). - Communications in Soil Science and Plant Analysis 25: 407-418. 